\section{An APL program for minimum-error Guttman scaling}

\section{DAVID J. H. DEAN and MARSHALL H. SEGALL Interdisciplinary Social Science Program Syracuse, New York 13210}

Computer programs which perform minimum-error Guttman scaling are not widely available. The most accessible program to perform any type of Guttman scaling is the SPSS (Nie, Hull, Jenkins, Steinbrenner, \& Bent, 1975) program, which uses the Goodenough (1944) procedure for counting errors. Unfortunately, according to McConaghy (1976), the statistical tests used to evaluate the scales produced by SPSS are based on the minimum-error rather than the Goodenough procedure. This discrepancy produces an overly conservative statistical test.

A program written to perform minimum-error Guttman scaling uses an error-counting technique and statistical tests that are consistent with each other. The program permits ambiguous score patterns that have minimum Guttman errors at two or more "true" score values to be treated in any of four different ways. These treatments include random selection among the possible score values, selection of the middle score, and selection of the highest or the lowest of the possible scores. The variety of alternatives illustrates the continuing nature of the controversy which still surrounds the scaling procedure (Dotson \& Summers, 1970; Henry, 1952; Wimberley, 1976).

Computer and Language. The program is written in the APL language for use at a computer terminal. The language and the program combine to permit a high degree of interaction between the user and the computer. The algorithms can be translated into FORTRAN, but would result in a program more than five times as long as the APL program. The program will function on any computer with an APL system.

Input. A matrix containing the data to be analyzed must be prepared before the program is executed Each row of the matrix represents a case; each column represents the responses to an item forming the scale. Responses must be coded in binary form, with 1 indicating than an item was passed and 0 indicating that an item was failed. Other input is requested during the execution of the program: specification of processing, statistics and output options, and the insertion of a title for each analysis.

Computational Procedure. The entire matrix (or any subset of columns selected by the user) is rearranged according to the number of cases passing each item. The response pattern of each case is then compared to a matrix of perfect-scale types. The number of Guttman errors associated with the comparison to each perfect scale is stored in an error vector. Unambiguous cases are assigned the score corresponding to the perfect-scale type which resulted in the fewest Guttman errors. Ambiguous cases are handled in one of four ways, depending on the user's preference. Statistics are computed after each case is assigned a "true" Guttman score. (See Appendix A for an example of perfect data; Appendix B shows random data.)

Output. The following information may be printed at the terminal or stored on an APL file for later printing on a high-speed line printer: (1) number of cases passing each item, (2) coefficient of reproducibility, (3) minimum marginal reproducibility, (4) percent improvement, (5) coefficient of scalability, (6) descriptive statistics and frequency distributions for "true" scores and for case-bycase Guttman errors, and (7) complete listing of scale score, number of errors, and response pattern for all cases.

Restrictions. The input data matrix should be limited to no more than 10,000 elements (e.g., 500 cases and 20 items).

Availability. Copies of this paper and a source listing with complete documentation may be obtained without charge from Marshall $H$. Segall, Interdisciplinary Social Science Program, Syracuse University, Syracuse, New York 13210.

Appendix A

Example of Perfect Data

\begin{tabular}{llllll}
\hline \multicolumn{7}{c}{ SAMPLE1 } & & \\
1 & 1 & 1 & 1 & 1 \\
1 & 1 & 0 & 1 & 1 \\
1 & 0 & 0 & 1 & 1 \\
1 & 0 & 0 & 0 & 1 \\
1 & 0 & 0 & 0 & 0 \\
1 & 1 & 1 & 1 & 1 \\
1 & 1 & 0 & 1 & 1 \\
1 & 0 & 0 & 1 & 1 \\
1 & 0 & 0 & 0 & 1 \\
1 & 0 & 0 & 0 & 0 \\
1 & 1 & 1 & 1 & 1 \\
1 & 1 & 0 & 1 & 1 \\
1 & 0 & 0 & 1 & 1 \\
1 & 0 & 0 & 0 & 1 \\
1 & 0 & 0 & 0 & 0
\end{tabular}


Appendix A Continued

SCALOGRAM SAMPLE1

SUMMARY DATA FOR OVERALL MATRIX AS ENTERED

MATRIX HAS 15 CASES (ROWS) AND 5 ITEMS (COLUMNS).

NUMBER OF CASES PASSING EACH ITEM

$\begin{array}{lrrrrr}\text {--ITEM NUMBERS-- } & 1 & 2 & 3 & 4 & 5 \\ \text { NUMBER OF PASSES } & 15 & 6 & 3 & 9 & 12\end{array}$

ENTER ITEM NUMBERS TO BE ANALYZED, OR ENTER 999 TO ANALYZE ALL ITEMS

口:

999

ENTER OPTION NUMBERS (OR TYPE 000 FOR HELP)

ENTER 3 NUMBERS--TO SPECIFY PROCESSING MODE, STATISTICS MODE, AND OUTPUT MODE D:

000

OPTION SPECIFICATION ERROR. PLEASE TRY AGAIN AFTER READING THESE INSTRUCTIONS YOU HAVE THREE OPTIONS WHICH MUST BE SPECIFIED.

THE FIRST OPTION SPECIFIES HOW AMBIGUOUS CASES ARE TO BE TREATED.

TYPE 1 IF THE COMPUTER IS TO PICK FROM THE POSSIBLE SCORES RANDOMLY.

TYPE 2 IF THE COMPUTER IS TO PICK THE HIGHEST OF THE POSSIBLE SCORES.

TYPE 3 IF THE COMPUTER IS TO PICK THE LOWEST OF THE POSSIBLE SCORES.

TYPE 4 IF THE COMPUTER IS TO PICK THE POSSIBLE SCORE NEAREST THE ACTUAL SCORE. (IF TWO SCORES ARE EQUALLY NEAR, THE COMPUTER PICKS FROM THESE AT RANDOM.)

YOUR SECOND OPTION SPECIFIES THE AMOUNT OF STATISTICS YOU WANT GENERATED.

TYPE $1 \mathrm{IF}$ YOU WANT ALL STATISTICS PRINTED AT THE TERMINAL.

TYPE 2 IF YOU WANT ONLY THE STANDARD GUTTMAN STATISTICS PRINTED.

TYPE 3 IF YOU WANT NO STATISTICS PRINTED AT THE TERMINAL.

YOUR THIRD OPTION SPECIFIES THE TYPE OF LISTING MODE YOU WANT PRINTED.

TYPE 1 IF YOU WANT NO CASES LISTED.

TYPE 2 IF YOU WANT 10 PERCENT OF THE CASES LISTED ON THE TERMINAL.

TYPE 3 IF YOU WANT ALL CASES LISTED ON THE TERMINAL.

TYPE 4 IF YOU WANT GUTTMAN STATISTICS AND CASES STORED ON AN APL FILE. --NOTE--THE APL FILE MUST BE CREATED PRIOR TO EXECUTION OF THE PROGRAM, AND THE FILE TIE MUST BE NUMBER 1.

ENTER 3 NUMBERS--TO SPECIFY PROCESSING MODE, STATISTICS MODE, AND OUTPUT MODE $\square:$

113

ANALYSIS IS NOW BEGINNING.

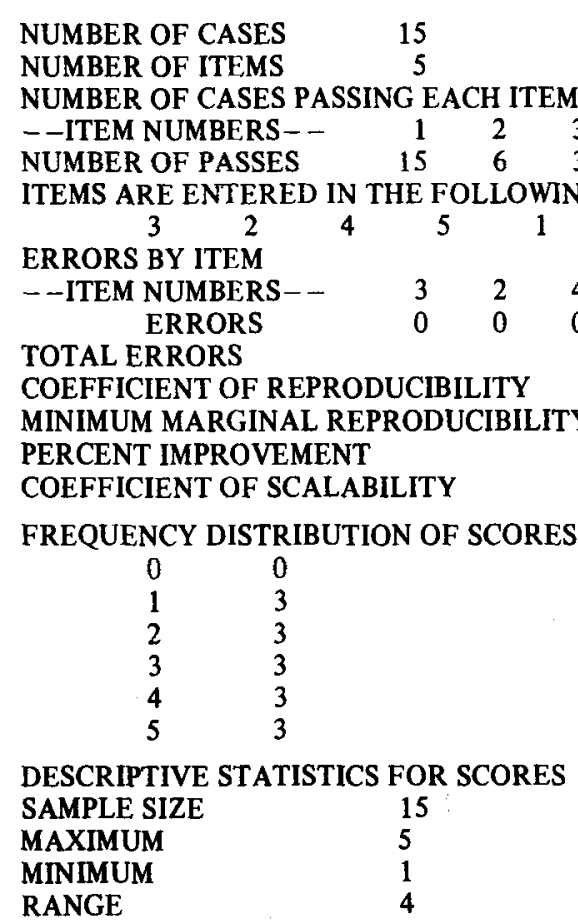


Appendix A Continued

\begin{tabular}{ll}
\hline MEAN & 3 \\
VARIANCE & 2.142857143 \\
STANDARD DEVIATION & 1.463850109 \\
MEAN DEVIATION & 1.2 \\
MEDIAN & 3
\end{tabular}

FREQUENCY DISTRIBUTION OF CASE BY CASE ERRORS

$0 \quad 15$

DESCRIPTIVE STATISTICS FOR CASE BY CASE ERRORS

$\begin{array}{ll}\text { SAMPLE SIZE } & 15 \\ \text { MAXIMUM } & 0 \\ \text { MINIMUM } & 0 \\ \text { RANGE } & 0 \\ \text { MEAN } & 0 \\ \text { VARIANCE } & 0 \\ \text { STANDARD DEVIATION } & 0 \\ \text { MEAN DEVIATION } & 0 \\ \text { MEDIAN } & 0\end{array}$

0 CASES HAD AMBIGUOUS ERROR PATTERNS, THEY WERE CASES- NOW LISTING CASES

AMBIG CASE ERROR SCORE - -ITEM NUMBERS--

$\begin{array}{rlllllll} & & & 3 & 2 & 1 & 5 & 1 \\ 1 & 0 & 5 & 1 & 1 & 1 & 1 & 1 \\ 6 & 0 & 5 & 1 & 1 & 1 & 1 & 1 \\ 11 & 0 & 5 & 1 & 1 & 1 & 1 & 1 \\ 2 & 0 & 4 & 0 & 1 & 1 & 1 & 1 \\ 7 & 0 & 4 & 0 & 1 & 1 & 1 & 1 \\ 12 & 0 & 4 & 0 & 1 & 1 & 1 & 1 \\ 3 & 0 & 3 & 0 & 0 & 1 & 1 & 1 \\ 8 & 0 & 3 & 0 & 0 & 1 & 1 & 1 \\ 13 & 0 & 3 & 0 & 0 & 1 & 1 & 1 \\ 4 & 0 & 2 & 0 & 0 & 0 & 1 & 1 \\ 9 & 0 & 2 & 0 & 0 & 0 & 1 & 1 \\ 14 & 0 & 2 & 0 & 0 & 0 & 1 & 1 \\ 5 & 0 & 1 & 0 & 0 & 0 & 0 & 1 \\ 10 & 0 & 1 & 0 & 0 & 0 & 0 & 1 \\ 15 & 0 & 1 & 0 & 0 & 0 & 0 & 1\end{array}$

Appendix B

Example of Random Data

\begin{tabular}{cccccc}
\hline \multicolumn{7}{c}{ Example of Random Data } \\
\hline & \multicolumn{7}{c}{ SAMPLE2 } \\
0 & 1 & 0 & 1 & 0 \\
0 & 1 & 1 & 1 & 0 \\
1 & 1 & 0 & 0 & 1 \\
1 & 0 & 0 & 0 & 0 \\
1 & 1 & 1 & 1 & 1 \\
0 & 1 & 0 & 1 & 1 \\
1 & 0 & 0 & 1 & 0 \\
1 & 1 & 1 & 0 & 0 \\
1 & 1 & 1 & 1 & 0 \\
1 & 1 & 0 & 0 & 1 \\
0 & 0 & 0 & 0 & 0 \\
0 & 1 & 1 & 0 & 1 \\
1 & 1 & 0 & 1 & 0 \\
0 & 0 & 1 & 0 & 1 \\
0 & 0 & 1 & 1 & 0
\end{tabular}

SCALOGRAM SAMPLE2

SUMARY DATA FOR OVERALL MATRIX AS ENTERED

MATRIX HAS 15 CASES (ROWS) AND 5 ITEMS (COLUMNS).

NUMBER OF CASES PASSING EACH ITEM

$\begin{array}{llllll}- \text {-ITEM NUMBERS - - } & 1 & 2 & 3 & 4 & 5\end{array}$

$\begin{array}{llllll}\text { NUMBER OF PASSES } & 8 & 10 & 7 & 8 & 6\end{array}$ 
Appendix B Continued

ENTER ITEM NUMBERS TO BE ANALYZED, OR ENTER 999 TO ANALYZE ALL ITEMS $\square$ :

999

ENTER OPTION NUMBERS (OR TYPE 000 FOR HELP)

ENTER 3 NUMBERS--TO SPECIFY PROCESSING MODE, STATISTICS MODE, AND OUTPUT MODE 口:

\section{3}

ANALYSIS IS NOW BEGINNING.

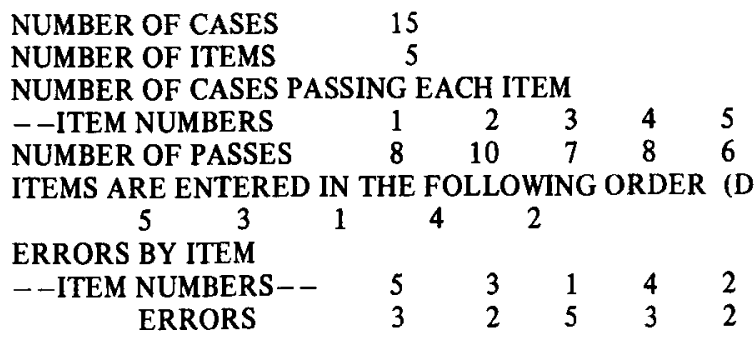

TOTAL ERRORS

COEFFICIENT OF REPRODUCIBILITY

MINIMUM MARGINAL REPRODUCIBILITY

PERCENT IMPROVEMENT

0.57333

COEFFICIENT OF SCALABILITY

FREQUENCY DISTRIBUTION OF SCORES

$\begin{array}{ll}0 & 3 \\ 1 & 1 \\ 2 & 2 \\ 3 & 2 \\ 1 & 4 \\ 5 & 3\end{array}$

DESCRIPTIVE STATISTICS FOR SCORES

$\begin{array}{ll}\text { SAMPLE SIZE } & 15 \\ \text { MAXIMUM } & 5 \\ \text { MINIMUM } & 0 \\ \text { RANGE } & 5 \\ \text { MEAN } & 2.8 \\ \text { VARIANCE } & 3.457142857 \\ \text { STANDARD DEVIATION } & 1.85933936 \\ \text { MEAN DEVIATION } & 1.573333333 \\ \text { MEDIAN } & 3\end{array}$

FREQUENCY DISTRIBUTION OF CASE BY CASE ERRORS

$\begin{array}{ll}0 & 5 \\ 1 & 5 \\ 2 & 5\end{array}$

DESCRIPTIVE STATISTICS FOR CASE BY CASE ERRORS

$\begin{array}{ll}\text { SAMPLE SIZE } & 15 \\ \text { MAXIMUM } & 2 \\ \text { MINIMUM } & 0 \\ \text { RANGE } & 2 \\ \text { MEAN } & 1 \\ \text { VARIANCE } & 0.7142857143 \\ \text { STANDARD DEVIATION } & 0.8451542547 \\ \text { MEAN DEVIATION } & 0.6666666667 \\ \text { MEDIAN } & 1\end{array}$

5 CASES HAD AMBIGUOUS ERROR PATTERNS. THEY WERE CASES - -

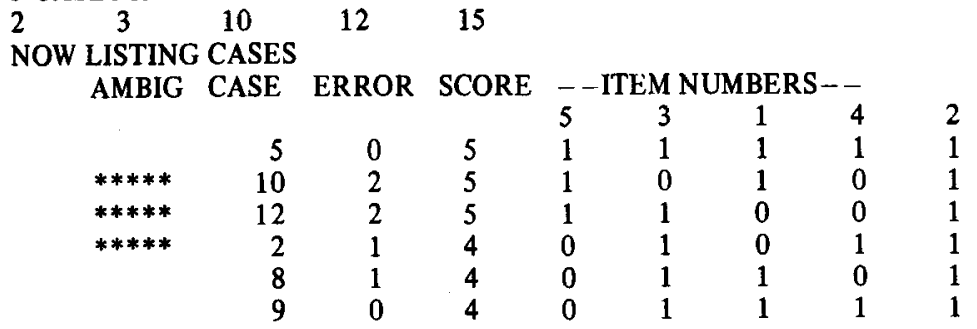




\begin{tabular}{crrrrrrrr}
\multicolumn{10}{c}{ Appendix B Continued } \\
\hline \multirow{10****}{*}{} & 15 & 2 & 4 & 0 & 1 & 0 & 1 & 0 \\
& 7 & 1 & 3 & 0 & 0 & 1 & 1 & 0 \\
& 13 & 0 & 3 & 0 & 0 & 1 & 1 & 1 \\
& 1 & 0 & 2 & 0 & 0 & 0 & 1 & 1 \\
& 6 & 1 & 2 & 1 & 0 & 0 & 1 & 1 \\
& 3 & 2 & 1 & 1 & 0 & 1 & 0 & 1 \\
PROCESSING COMPLETED & 4 & 1 & 0 & 0 & 0 & 1 & 0 & 0 \\
& 11 & 0 & 0 & 0 & 0 & 0 & 0 & 0 \\
& 14 & 2 & 0 & 1 & 1 & 0 & 0 & 0
\end{tabular}

\section{REFERENCES}

Dotson, L. E., \& Summers, G. F. Elaboration of Guttman scaling techniques. In G. F. Summers (Ed.), Attitude measurement. Chicago: Rand-McNally, 1970.

Goodenough, W. H. A technique for scale analysis. Educational and Psychological Measurement, 1944, 4, 179.190.

HENRY, A. F. A method of classifying non-scale response patterns in a Guttman scale. Public Opinion Quarterly, 1952, 16. $94 \cdot 106$.
McConaghy, M. J. Maximum possible error in Guttman scales. Public Opinion Quarterly, 1976, 39, 343-357.

Nie, N. H., Hull, C. H., Jenkins, J. G., Steinbrenner, K., \& BENT, D. H. Statistical package for the social sciences (2nd ed.). New York: McGraw-Hill, 1975.

Wimberley, R. C. ALAM and ALAS: Questioning error assignments in unidimensional Guttman scaling. Educational and Psychological Measurement, 1976, 36, 361-367.

(Accepted for publication February 7, 1978.) 